\title{
PERAN PENDIDIKAN JASMANI DAN OLAHRAGA PADA LEMBAGA PENDIDIKANDI INDONESIA
}

\author{
Sabaruddin Yunis Bangun \\ Fakultas Ilmu Keolahragaan Universitas Negeri Medan \\ unisbgn@unimed.ac.id
}

\begin{abstract}
ABSTRAK
Pendidikan Jasmani dan Olahraga di Lembaga Pendidikan harus ditekankan pada olahraga kesehatan dan latihan jasmani untuk meningkatkan derajat sehat dinamis dan kemampuan motorik dan koordinasi yang lebih baik. Agar para siswa selama masa belajar memiliki kualitas hidup yang lebih baik, serta dapat diharapkan dapat berprestasi di bidang akademik dan olahraga sehingga menjadi sumber daya manusia yang bermutu di masa depan. Tujuan tulisan ini adalah sebagai referensi awal peran Peran Pendidikan Jasmani dan Olahraga di lembaga pendidikan Indonesia, dengan pemikiran bersama. Tentunya dalam kerangka membangun kembali pendidikan di Indonesia yang semakin lama semakin terpuruk dari segi pengelolaan. Pemanfaatan ilmu pengetahuan dan teknologi serta konsep pendidikan yang kurang jelas kontribusinya pada kualitas sumber daya manusia dalam pembangunan Indonesia, dalam hal ini kaitannya dengan program-program yang selama ini telah berjalan. Pemerintahan Indonesia harus berbenah diri dulu dengan menjadikan pendidikan jasmani dan olahraga sebagai kebutuhan dan pemerintah tertinggi harus memiliki komitmen yang kuat dan fokus dalam memajukan pendidikan jasmani dan olahraga di tanah air. Pemerintahan adalah kunci utama, pengambil kebijakan dan memajukan pendidikan di tanah air. Pemerintah dan para menteri terkait harus sinergis dan koordinasi yang baik dalam memajukan pendidikan jasmani dan olahraga pada lembaga pendidikan menuju Indonesia berkualitas Internasional.
\end{abstract}

Kata Kunci: Pendidikan Jasmani dan Olahraga

\section{PENDAHULUAN}

Pendidikan jasmani di Indonesia memiliki tujuan kepada keselarasan antara tubuhnya badan dan perkembangan jiwa, dan merupakan suatu usaha untuk membuat bangsa Indonesia yang sehat lahir dan batin, diberikan kepada segala jenis sekolah. (UU No. 4 tahun 1950, tentang dasar-dasar pendidikan dan pengajaran di sekolah bab IV pasal 9).

Pendidikan jasmani mempunyai tujuan pendidikan sebagai (1) perkembangan organorgan tubuh untuk meningkatkan kesehatan dan kebugaran jasmani, 2) perkembangan neuro muscular, 3) perkembangan mental emosional, 4) perkembangan sosial dan 5) perkembangan intelektual. Pendidikan Jasmani dan Olahraga merupakan bagian dari kurikulum standar Lembaga Pendidikan Dasar dan Menengah. Dengan pengelolaan yang tepat, maka pengaruhnya bagi pertumbuhan dan perkembangan Jasmani, Rohani dan Sosial Peserta didik tidak pernah diragukan. Sayangnya Pendidikan Jasmani dan Olahraga di Lembaga-lembaga Pendidikan belum dapat memposisikan dirinya pada tempat yang strategis pada dunia pendidikan, bahkan masih sering di abaikan; misalnya pada masa-masa menjelang ujian akhir sesuatu jenjang Pendidikan. Maka Pendidikan Jasmani dan Olahraga dihapuskan dengan alasan agar para siswa dalam belajarnya untuk menghadapi ujian akhir "tidak terganggu".

Oleh karena itu Pendidikan Jasmani dan Olahraga di Sekolah tidak saja memerlukan reposisi, tetapi juga perlu reorientasi, reaktualisasi dan revitalisasi dalam pemikiran dan pengelolaannya untuk mendapatkan tempatnya yang terhormat. Untuk memahami hal ini perlu lebih dahulu di pahami apa yang menjadi dasar bagi perlunya diselenggarakan Pendidikan Jasmani dan Olahraga di Sekolah. Makna dan Misi Pendidikan Jasmani dan Olahraga di Lembaga Pendidikan.Lembaga Pendidikan adalah Lembaga formal yang terpenting untuk pembinaan mutu sumber daya manusia. Dalam Lembaga Pendidikan, siswa dibina untuk menjadi sumber daya manusia yang unggul dalam aspek jasmani, rohani dan sosial melalui berbagai bentuk media pendidikan dan keilmuan yang sesuai.

Acuan tertinggi mutu sumber daya manusia adalah SEHAT WHO yaitu sumber daya manusia yang Sejahtera jasmani, rohani 
dan sosial, bukan hanya bebas dari penyakit, cacat ataupun kelemahan. Sehat WHO adalah konsep sehat yang menjadi cita-cita, tujuan atau acuan pembinaan mutu sumber daya manusia yaitu sehat sempurna, sehat ideal atau sehat/sejahtera paripurna, yang merupakan hal yang hampir mustahil untuk dapat dicapai.

Pendidikan Jasmani adalah kegiatan jasmani yang diselenggarakan untuk menjadi media bagi kegiatan pendidikan. Pendidikan adalah kegiatan yang merupakan proses untuk mengembangkan kemampuan dan sikap rohaniah yang meliputi aspek mental, intelektual dan bahkan spiritual. Sebagai bagian dari kegiatan pendidikan, maka pendidikan jasmani merupakan bentuk pendekatan ke aspek sejahtera Rohani (melalui kegiatan jasmani), yang dalam lingkup sehat WHOberarti sehat rohani.

Olahraga adalah kegiatan pelatihan jasmani, yaitu kegiatan jasmani untuk memperkaya dan meningkatkan kemampuan dan ketrampilan gerak dasar maupun gerak ketrampilan (kecabangan olahraga). Kegiatan itu merupakan bentuk pendekatan ke aspek sejahtera jasmani atau sehat jasmani yang berarti juga sehat dinamis yaitu sehat yang disertai dengan kemampuan gerak yang memenuhi segala tuntutan gerak kehidupan sehari-hari. Artinya setiap orang yang melakukan pendidikan jasmani melalui aktivitas olahragaakan memiliki tingkat kebugaran jasmani yang memadai.Olahraga massal adalah bentuk kegiatan olahraga yang dapat dilakukan oleh sejumlah besar orang secara bersamaan atau yang biasa disebut sebagai olahraga masyarakat yang hakekatnya adalah olahraga kesehatan, sebab dalam melakukan kegiatan olahraga tersebut hanya satu tujuannya yaitu memelihara atau meningkatkan derajat kesehatan dan aktivitas gerak.

Olahraga masyarakat atau olahraga kesehatan dengan demikian merupakan bentuk olahraga yang dapat mewujudkan kebersamaan dan kesetaraan dalam berolahraga, oleh karena pada olahraga itu tidak ada tuntutan keterampilan olahraga tertentu. Dengan demikian maka olahraga kesehatan atau olahraga masyarakat merupakan bentuk pendekatan ke aspek sejahtera sosial (sehat sosial $=$ kebugaran sosial). Demikianlah maka Pendidikan Jasmani dan Olahraga di Lembaga Pendidikan mempunyai tujuan membina mutu sumber daya manusia seutuhnya yaitu manusia yang sehat/bugar seutuhnya atau sejahtera seutuhnya yaitu sejahtera jasmani, rohani dan sosial sesuai rumusan sehat WHO.

Tujuan tulisan ini adalah sebagai referensi awal peran Peran Pendidikan Jasmani dan Olahraga di lembaga pendidikan Indonesia, dengan pemikiran bersama. Tentunya dalam kerangka membangun kembali pendidikan di Indonesia yang semakin lama semakin terpuruk dari segi pengelolaan. Pemanfaatan ilmu pengetahuan dan teknologi serta konsep pendidikan yang kurang jelas kontribusinya pada kualitas sumber daya manusiadalam pembangunan Indonesia, dalam hal ini kaitannya dengan program-program yang selama ini telah berjalan.

Manfaat dari tulisan pada makalah ini sebagai pemikiran bagi (1) Anggota MPR/DPR dan DPRD sebagai pengusul kebijakan dan pengambilan keputusan dalam memajukan pendidikan dan mensejahterakan masyarakat di seluruh Indonesia (2) Menteri Pendidikan dan Kebudayaan beserta direktorat terkait, Rektor seluruh Indonesia sebagai pembuat kebijakan di perguruan tinggi masing-masing (3) Pemerintah Pusat dan Pemerintah Daerah pembuat kebijakan untuk memajukan pendidikan di Indonesia (4) Kepala Dinas Provinsi dan Daerah, pakar serta ilmuan pendidikan dan ilmuan keolahragaan, guru dan dosen terkait sebagai tenaga pendidikan di seluruh Indonesia (5) Para Pelajar seluruh Indonesia yang akan berprestasi tinggi, (6) Pengurus/Pembina lembagalembagapendidikan di seluruh Indonesia, dan (8) Masyarakat Indonesia yang sadar akan manfaat dan peranan pendidikan jasmani dan olahraga pada lembaga pendidikan di Indonesia.

\section{KAJIAN PUSTAKA \& PEMBAHASAN}

\section{Hakekat Pendidikan Jasmani}

Pendidikan jasmani merupakan bagian yang tidak dapat dipisahkan dari pendidikan keseluruhan karena pendidikan jasmani menggunakan aktivitas jasmani sebagai pokok dari proses pembelajaran. Secara psikologis pendidikan yang menggunakan fisik sangat penting bagi perkembangan dan kemajuan peserta didik, dengan demikian belajar pendidikan jasmani sangat penting. Belajar sebagai proses yang aktif, learning by doing. Belajar dengan jalan melakukannya. Tidak ada belajar tanpa aktivitas, baik aktivitas fisik maupun mental. 
Pendidikan jasmani adalah bagian integral dari pendidikan secara total yang berkontribusi pada perkembangan individual melalui media alamiah aktivitas jasmani gerak insani. Pendidikan jasmani adalah urutan pengalaman belajar yang direncanakan secara seksama, dirancang untuk memenuhi perkembangan dan pertumbuhan, dan kebutuhan perilaku setiap siswa. Tujuan yang ingin dicapai bersifat menyeluruh dan memerlukan waktu jangka panjang, maka dapat dirumuskan kedalam beberapa tujuan jangka pendek, dengan tidak melupakan tujuan hakiki yang ingin dicapai.

Tujuan itu dirumuskan kedalam tujuan pengajaran pendidikan jasmani sebagai berikut: (1) Mengembangkan keterampilan fisikal, yang memungkinkan siswa berpartisipasi dalam berbagai aktivitas jasmani, (2) Mengembangkan kebugaran fisikal dan berfungsi normalnya sistem tubuh untuk hidup aktif siswa pada lingkungannya masingmasing, (3) Mengembangkan pengetahuan dan pemahaman keterampilan fisikal dan sosial, kebugaran jasmani, prinsip-prinsip ilmiah gerak, dan hubungan latihan jasmani dengan kesejahteraan personal setiap orang, (4) Mengembangkan keterampilan sosial yang mempromosikan standar penerimaan perilaku dan hubungan positif dengan orang lain, (5) Mengembangkan sikap dan apresiasi yang menggugah partisipasi dan kenikmatan beraktivitas jasmani, kebugaran, kualitas penampilan, self konsep positif dan respek terhadap orang lain.

Tabrani Rusyan dkk, menyatakan sebagai berikut: belajar merupakan suatu interaksi antara peserta didik dengan guru dalam rangka mencapai tujuan. Lebih lanjut Winaranto menjelaskan: Pendidikan Jasmani dan olahraga makin penting dan strategis dalam kehidupan era teknologi yang sarat perubahan, persaingan dan kompleksitas. Hal tersebut menyangkut pembentukan watak dan kepribadian bangsa serta usaha pengembangan dan peningkatan mutu sumber daya manusia secara berkelanjutan.Pendidikan jasmani mempunyai dampak yang luas, oleh karena itu harus terus diupayakan sebagai kegiatan prioritas dalam pendidikan, secara jelas karena pendidikan jasmani dapat mengembangkan dan meningkatkan sumber daya manusia yang pada jaman sekarang ini sangat diperlukan.

Pada jaman era globalisasi yang ditandai oleh kompetisi dengan teknologi yang semakin canggih menjadi ciri khas dunia sekarang ini, maka pendidikan jasmani menjadi penting untuk meningkatkan kesegaran jasmani dan sikap mental kompetitif yang membaja.

Pendidikan jasmani menyiapkan dan meningkatkan mutu sumber daya manusia yang tangguh dan tanggap menghadapi kehidupan modern yang sarat perubahan, persaingan dan kompleksitas. Menurut Wiranto; Pendidikan jasmani meningkatkan disiplin, keterampilan berkomunikasi dan bekerjasama, kecerdasan dan kreatifitas, kepribadian yang sehat, moral dan etika, kepemimpinan dan mengembangkan kecerdasan emosional.

Pendidikan jasmani yang diberikan kepada siswa di sekolah menjadii bagian penting karena pendidikan jasmani merupakan bagaian integral dari pendidikan keseluruhan, oleh karena itu tidaklah lengkap jika pendidikan tanpa pendidikan jasmani, hal ini sesuai dengan SK Mendikbud No:413/U/1987 yang dikemukakan oleh Abdulkadir Ateng sebagai berikut: pendidikan jasmani merupakan bagian integral dari pendidikan secara keseluruhan yang bertujuan mengembangkan individu secara organik, neuromuskuler, intelektual dan emosional melalui berbagai aktivitas jasmani.

Pendidikan jasmani akan sangat melengkapi tercapainya tujuan pendidikan secara keseluruhan, karena guru pendidikan jasmani diharapkan mampu melakukan berbagai pengembangan strategi pembelajaran, karena pembelajaran pendidikan jasmani berlangsung di luar kelas sehingga tidak hanya dibatasi oleh dinding tembok hanya membatasi gerak peserta didik dalam mengekpresikan potensi dan bakat gerak yang dimiliki.

Nana Sudjana berpendapat: Sumber belajar untuk tujuan pengajaran yaitu untuk mendukung kegiatan belajar mengajar. Kriteria ini paling umum dipakai oleh guru dengan maksud untuk memperluas bahan pelajaran, melengkapi berbagai kekurangan bahan, sebagai kerangka mengajar yang sistematis.

Pendidikan jasmani pada intinya adalah belajar gerak yang dilakukan secara benar pada guru yang memang ahlinya, keteraturan pembelajaran pendidikan jasmani telah disusun oleh beberapa ahli pendidikan jasmani hall ini dikuatkan dengan pernyataan Nana Sudjana sebagai berikut: Belajar keterampilan motorik banyak hubungan dengan kesanggupan menggunakan gerakan badan sehingga memiliki rangkaian urutan gerakan relatif teratur, luwes, tepat, cepat, dan lancar. 
Pendidikan jasmani memiliki dampak dan pengaruh yang luas bagi proses pendidikan secara menyeluruh karena ternyata banyak pakar yang memahami dan memprediksi pengaruh pendidikan jasmani jika pembelajarannya telah berjalan dengan benar.

Aip Syarifuddin mengemukakan pendapat: Pendidikan Jasmani adalah pendidikan yang mengaktualisasikan potensi-potensi aktivitas manusia berupa sikap, tindak dan karya yang diberi isi, bentuk dan arah menuju kebulatan kepribadian sesuai dengan cita-cita kemanusiaan.Pendidikan jasmani merupakan aktivitas fisik sebagai inti dari pembelajaran sehingga pendidikan jasmani hanya sebgai sarana, hal inii menurut Declaration On Sport sebagai berikut:Pendidikan jasmani adalah suatu proses pendidikan seseorang sebagai individu maupun sebagai anggota masyarakat yang dilakukan secara sadar dan sistematik melalui berbagai kegiatan jasmani dalam rangka memperoleh peningkatan kemampuan dan keterampilan jasmani, pertumbuhan kecerdasan dan pembentukan watak.

Abdulkadir Ateng juga menyatakan tentang pendidikan jasmani sebagai suatu proses pendidikan secara keseluruhan oleh karena itu tidaklah dinamakan pendidikan jika tidak ada pendidikan jasmaninya, hal ini dinyatakan sebagai berikut: Usaha pendidikan dengan menggunakan aktivitas otot-otot besar hingga proses pendidikan yang berlangsung tidak terhambat oleh gangguan kesehatan dan pertumbuhan badan. Pendidikan jasmani sebagai aktivitas fisik yang merupakan bagian dari proses pendidikan yang dapat mengembangkan kesegaran jasmani, organorgan tubuh dan intelektual serta pengendalian emosi hal ini dinyatakan sebagai berikut:Pendidikan jasmani sebagai sebuah aspek dari proses pendidikan keseluruhan dengan menggunakan menekankan aktivitas yang mengembangkan fitness, fungsi organ tubuh, kontrol neuromuscular, kekuatan intelektual dan pengendalian emosi.

Pendidikan jasmani yang dilaksanakan di sekolah akan membantu terbentuknya intelektual serta perkembangan individu sebagai makhluk sosial hal ini dinyatakan oleh Syarifudin tentang pendidikan jasmani sebagai berikut: Pendidikan jasmani adalah pendidikan yang memiliki tujuan untuk membantu perkembangan organik, perkembangan neuromuskular, perkembangan intelektual dan perkembangan individu-sosial siswa.
Menurut para ahli di atas maka disimpulkan bahwa pengertian pendidikan jasmani dalam tulisan ini adalah suatu pendidikan yang dilaksanakan pada setiap jenjang pendidikan mulai dari sekolah dasar sampai sekolah menengah yang menggunakan aktivitas atau anggota fisik untuk mencapai kesehatan dan kebugaran fisik, keterampilan gerak yang berakibat pada berkembangnya kemampuan sikap dan intelektual pada kehidupan sehari-hari.

\section{Hakekat Olahraga}

Olahraga merupakan aktivitas yang sangat penting untuk mempertahankan kebugaran seseorang. Olah raga juga merupakan salah satu metode penting untuk mereduksi stress. Cara Pedia menyampaikan media on line olah raga juga merupakan suatu perilaku aktif yang menggiatkan metabolisme dan mempengaruhi fungsi kelenjar di dalam tubuh untuk memproduksi sistem kekebalan tubuh dalam upaya mempertahankan tubuh dari gangguan penyakit serta stress. Oleh karena itu, sangat dianjurkan kepada setiap orang untuk melakukan kegiatan olahraga secara rutin dan tersetruktur dengan baik. Yaitu ikut serta dalam aktivitas fisik untuk mendapatkan kesenangan, dan aktivitas khusus seperti berburu atau dalam olahraga pertandingan (athletic games di Amerika Serikat).

Makna olahraga menurut ensiklopedia Indonesia adalah gerak badan yang dilakukan oleh satu orang atau lebih yang merupakan regu atau rombongan. Sedangkan dalam Webster's New Collegiate Dictonary (1980). Untuk penjelasan pengertian olahraga menurut Edward (1973) olahraga harus bergerak dari konsep bermain, games, dan sport. Ruang lingkup bermain mempunyai karakteristik antara lain; (a) Terpisah dari rutinitas, (b) Bebas, (c) Tidak produktif, (d) Menggunakan peraturan yang tidak baku. Ruang lingkup pada games mempunyai karakteristik; a. ada kompetisi, b. hasil ditentukan oleh keterampilan fisik, strategi, kesempatan. Sedangkan ruang lingkup sport; permainan yang dilembagakan.

Menurut Cholik Mutohir (On Line) olah raga adalah proses sistematik yang berupa segala kegiatan atau usaha yang dapat mendorong mengembangkan, dan membina potensi-potensi jasmaniah dan rohaniah seseorang sebagai perorangan atau anggota masyarakat dalam bentuk permainan, perlombaan/pertandingan, dan prestasi puncak 
dalam pembentukan manusia Indonesia seutuhnya yang berkualitas berdasarkan Pancasila.

Ary Sudarsono di media on line juga menyampaikan bahwa olahraga juga bisa membuat rasa sportifitas dan kreatifitas serta menumbuhkan rasa persaudaraan. Berolahraga Merupakan Bagian dan Kebutuhan Hidup Salah satu karakteristik makhluk hidup di dunia ini, termasuk manusia adalah melakukan gerakan. Antara manusia dan aktivitas fisik merupakan dua hal yang sulit atau tidak dapat dipisahkan. Hal ini dapat dilihat bahwa sejak manusia pada jaman primitif hingga jaman moderen, aktivitas fisik atau gerak selalu melekat dalam kehidupan sehari-harinya. Berarti aktivitas fisik selalu dibutuhkan manusia.

Pada jaman primitif gerakan pada mulanya merupakan gejala emosional murni yang dilakukan manusia untuk kesenangan dan komunikasi dengan dewa. Selanjutnya, gerakan berkembang dari pelaksanaan gerak yang tidak terencana ke kondisi gerak yang hingar-bingar pada upacara seremonial dan komunikasi untuk kerja seni. Karena aktivitas gerak sangat penting baik untuk kelang ᄀsungan hidup maupun komunikasi dengan dewa, maka aktivitas fisik tersebut merupakan yang terpenting untuk eksistensi manusia

Oleh karena itu, mereka mulai menyusun struktur geraknya ke dalam bentuk-bentuk yang bermanfaat, tepat dan sadar. Semua peristiwa penting dalam siklus kehidupan orang primitif yang memiliki makna praktis dan religius disimbulkan dalam gerakangerakan tubuh yang terstruktur. Di seluruh periode evolusinya, aktivitas fisik sangat penting untuk kelangsungan hidup dan tetap penting untuk pertumbuhan dan perkembangan yang optimum.

Secara internal, gerak manusia terjadi secara terus menerus, dan secara eksternal, gerak manusia dimodifikasikan oleh pengalaman belajar, lingkungan yang mengitari, dan situasi yang ada. Oleh karena itu, manusia harus disiapkan untuk memahami fisiologis, psikologis dan sosiologis agar dapat mengenali dan secara efisien menggunakan komponen-komponen gerak secara keseluruhan. Dengan demikian, antara manusia dan aktivitas fisik tidak dapat dipisahkan dari kehidupannya.

\section{Pendidikan Jasmani dan Olahraga}

Kata olahraga atau sport menurut sejarahnya berasal dari bahasa latin abad pertengahan "disportare" yang berarti bersenang-senang, berpoya-poya, kemudian diketemukan kembali dalam kata Perancis kuno "desport" yang artinya juga bersenangsenang, berpoya-poya, atau mengabiskan waktu. Jadi sport bukan berasal dari bahasa Inggris, meskipun kebanyakan bangsa-bangsa banyak mengimpornya dari Inggris. Sport tidak sama dengan permainan (game), dapat dikatakan permainan lebih luas dari sport. Yang jelas sport mempunya ciri permainan (Harsuki, 1982). Unsur kompetisi telah dikenal sebagai ciri lain yang sangat menonjol dalam sport. Istilah permainan atau game sekarang sudah menjadi umum dipakai untuk pekan olahraga atau pesta olahraga seperti "Olympic Game", asian Game".

Telah disadari bahwa dalam istilah atau pengertian olahraga di Indonesia telah mencakup pengertian "sport" dan physical education atau pendidikan jasmani. Telah banyak definisi olahraga yang meliputi pengertian "sport" dan "physical education" dicoba untuk dikemukakan. Masalahnya apakah definisi tersebut sudah memadai untuk mencakup kedua pengertian sport dan pendidikan jasmani. Beberapa pendapat tentang definisi olahraga sebagai berikut: (1) KONI. Olahraga merupakan kebutuhan manusia yang bersumber atas kebesaran Tuhan Yang Maha Esa yang merupakan salah satu aspek dan unsur yang berpengaruh dalam pembangunan (2) KEPRES No. 131. tahun 1962 adalah: Segala kegiatan/usaha untuk mendorong, membangkitkan, mengembangkan dan membina kekuatan-kekuatan jasmani maupun rohaniah pada setiap manusia. (3) Dit. Jen PLSPO. Olahraga adalah suatu bentuk pendidikan individu dan masyarakat yang memanfaatkan kapasitas fisik manusia yang dilakukan secara sadar, sistematis dan terarah menuju kualitas hidup yang lebih tinggi.

Para ahli di Eropa dan Amerika berpendapat bahwa pendidikan jasmani adalah bagian yang integral dari pendidikan secara keseluruhan. Pendidikan jasmani menurut Cowell dan Hazelton adalah: "Physical education as a valuabel and integral part of organized education, is the sosial process of change in the behavior of the human organism resulting from participation in the big muscle and activities". Sedangkan Barrow berpendapat bahwa: "Physical education my 
be defined as education through big muscle play activity such as sport, exercise, and dance, where education's objectives may be achieved in part". Sedangkan Bucher memberikan definisi sebagai berikut: "Physical education, an intergral part of the total education process, is a field or endeavor the has its aim the development of physicaly, mentality, emotionally and socially fit citizen through the medium of physical activities that have been selected with a view to realizing these out comes".

Selanjutnya Hetherington mencatat dua hal dimana physical education saling berkaitan. Pertama, physical education bekaitan dan bersangkut paut dengan kegiatan otot-otot besar dan faedahnya. Kedua, dengan kotribusinya pada kesehatan dan pertumbuhan pada anak-anak sehingga ia dapat merealisasikan sebanyak mungkin dari proses pendidikan tanpa mengalami hambatan pertumbuhan.

Nash, menunjukan bahwa physical education adalah suatu fase dari proses pendidikan keseluruhan, dan menggunakan dororngan kegiatan tersebut yang sepadan pada tiap individu untuk mengembangkan individu tersebut secara organis, neuro musculair, intelectual dan emotonal. Hal tersebut bisa terealisir bilamana kegiatan pendidikan jasmani dilakukan ditempat-tempat seperti playground, gymnasium dan swimming pool. Nixon dan Cozens, menyatakan bahwa physical education adalah suatu fase dari proses pendidikan keselurahan yang berkaitan dengan kegiatan yang mengerahkan kekuatan secara penuh dengan mengikut sertakan sistem otot-otot dan belajar yang dihasilkan dari ikut sertanya dalam kegiatan lain.

Dari beberapa definisi yang dikemukakan oleh para ahli tersebut, terdapat tiga butir yang menonjol yang dapat kita catat sebagai berikut: (1) Bahwa pendidikan jasmani adalah bagian yang integral dari pendidikan keseluruhan, (2) Bahwa pendidikan jasmani menggunakan otototot besar, menggunakan kekuatan secara penuh dengan mengikut sertakan sistem otototot, atau menggunakan kekuatan otot yang dipilih atau diperoleh dari kegiatan tersebut, (3) Bahwa pendidikan jasmani bertujuan membangkitkan individu secara organis, neuromuscular, intelectual dan emosional.

Banyak orang beranggapan bahwa keberhasilan olahraga identik dengan perolehan medali dalam suatu event. Anggapan demikian tidak salah, tetapi tidak seluruhnya benar. Sebab, dalam setiap pertandingan multi event, perolehan medali memang menjadi ukuran keberhasilan suatu daerah atau negara dalam mengembangkan prestasi olahraganya. Tetapi sebenarnya, medali hanyalah satu aspek, dan bukan satu-satunya tujuan. Selain itu, olahraga prestasi hanyalah salah satu pilar dari dua pilar bangunan olahraga lainnya, yaitu: olahraga masyarakat dan pendidikan jasmani. Ada filosofi dasar yang jauh lebih esensial dari hanya sekedar perolehan medali, yakni "spirit Olypism" yang ajaran dasarnya adalah penghormatan terhadap nilai-nilai kemanusiaan (celebrition of humanity). Atas dasar tersebut, harus ditingggalkan upaya primitif-destruktif: atas nama medali, atlet menggunakan berbagai cara untuk mendapatkannya seperti menggunakan obatobatan perangsang, untuk mencapai kemenangan.

Terlepas itu semua, konsekuensi adanya keberhasilan pembangunan pendidikan, manusia menjadi semakin sadar akan hakhaknya seperti hak mendapatkan pekerjaan, hak berpolitik, hak ekonomi, dan termasuk hak melakukan aktivitas olahraga. Hanya saja hak untuk dapat melakukan olahraga tampaknya belum menjadi hak yang harus diperjuangkan sebagaiman hak-hak yang lain.

Ini setidaknya dapat kita lihat ketika sejumlah lapangan telah dialih fungsikan menjadi tempat-tempat bisnis. Di berbagai daerah, kondisi tersebut telah dan sedang terjadi seolah sambung menyambung tiada henti. Sayangnya, tidak seorang pun tampil menggugat tidak ada masyarakat yang peduli, misalnya dengan melakukan protes. Padahal mereka (anak-anak, para remaja, dan masyarakat pada umumnya) telah merasakan sulitnya mencari tempat untuk bermain dan berolahraga.

Hak untuk bermain dan atau berolahraga merupakan sesuatu yang Universal dan telah dinyatakan secara tegas oleh PBB dalam sebuah deklarasinya. "The United Nation and its member states affirm their commitment to the right to play in the 1989 UN Declaration on the rights of the child" (Olympic Aid \& WHO, 2002: 4). Dalam rancangan UndangUndang Keolahragaan Nasional juga disebutkan bahwa: (1) Setiap warga negara memiliki kesempatan yang sama (tanpa diskriminasi) untuk melakukan kegiatan olahraga, (2) Setiap warga negara berhak memilih dan mengikuti jenis olahraga yang diminati, (3) Setiap warga negara berhak 
memperoleh pelayanan berolahraga untuk mencapai derajat kesehatan dan kebugaran jasmani; dan atau memperoleh bimbingan prestasi bagi mereka yang berbakat, (4) Pemerintah berkewajiban memberikan dukungan dana, ruang terbuka, dan tenaga keolahragaan (guru/pelatih) guna mewujudkan pembangunan olahraga.

\section{Pendidikan Jasmani dan Olahraga di Lembaga Pendidikan}

Dalam perkembangan dunia pendidikan Indonesia yang semerawut, sejauh manakah kontribusi dari pendidikan jasmani? Pendidikan jasmani dalam konteks pendidikan nasional masih dianggap belum begitu penting oleh para pengambil kebijakan pendidikan Nasional. Dengan demikian akan sulit mengharapkan Pendidikan jasmani dan olahraga dapat berperan besar dalam menata sistem pendidikan yang semerawut ini. Kondisi ini sangat berbeda dengan perkembangan Pendidikan jasmani dan olahraga di negara-negara maju dan berkembang.

Di negara maju khususnya Eropa: "Physical education and sport sudah menjadi sebuah kebutuhan dan menjadi alat untuk integrasi sosial pemuda". Namun langkah yang realistis untuk Perkembangan Pendidikan jasmani dan olahraga di Indonesia agar dapat berperan nyata di kemudian hari adalah: (1) Menata dan memperkuat kajian keilmuan Pendidikan jasmani dan olahraga yang berawal dari lembaga tinggi keolahragaan dan jenjang pendidikan tinggi. Dewasa ini itu merupakan langkah yang tidak mudah, karena visi dan misi serta implementasi pengelolaan lembaga tinggi keolahragaan dan pendidikan tinggi tidak jelas bahkan boleh dikatakan merupakan bagian yang paling semerawut dari sistem kelembagaan di Indonesia ini; dan (2) Alumni pendidikan tinggi olahraga yang berada dalam sistem dan pengambil kebijakan pendidikan (Dikbud, Bappenas, Menpora dan DPR), merupakan posisi strategis dan harus lebih berperan dalam mewarnai kebijakan yang lebih mengarah kepada kemajuan pendidikan jasmani dan olahraga dan ilmu keolahragaan. Bukan hanya sekedar untuk menyelenggarakan berbagai event olahraga yang tidak jelas arahnya dan mementingkan kepentingan pribadi dan kelompok.

Harusnya salah satu out come yang ditimbulkan setelah belajar pendidikan jasmani dan olahraga adalah membuat pemuda di Indonesia ini maju dan dapat berpikir kreatif serta inovatif. Memiliki pemikiran yang positif dan jernih, sehingga dapat bertindak tanpa merugikan orang lain? Pada kenyataannya: (1) Pendidikan jasmani dan olahraga di sekolah masih dianggap mata pelajaran yang tidak penting sehingga implementasinya pelajaran pendidikan jasmani dan olahraga di sekolah dihadapkan pada berbagai masalah, selain masalah kualitas guru yang rendah, inpra stuktrur yang lemah, keterbatasan alat dan fasilitas olahraga sangat terbatas menjadi kendala umum di sekolah-sekolah. Dengan kondisi ini jelas mengharapkan pendidikan jasmani dan olahraga menjadi alat yang ampuh bagi pembinaan generasi muda anak bangsa kita bagaikan pungguk merindukan bulan.

\section{Pembahasan}

Sehat adalah kebutuhan dasar bagi segala aktivitas kehidupan. Jadi sehat harus dipelihara dan bahkan ditingkatkan. Cara terpenting, termurah dan fisiologis adalah melalui Olahraga Kesehatan. Dalam hubungan dengan nikmatnya kebutuhan dasar ini maka seluruh Siswa/Peserta didik memerlukan Olahraga baik sebagai konsumsi yaitu mendapatkan manfaatnya langsung dari melakukan kegiatan Olahraga, maupun kegiatan Olahraga sebagai media bagi Pendidikannya.

Lembaga Pendidikan adalah Lembaga formal terpenting yang membina mutu sumber daya manusia. Pembinaan mutu sumber daya manusia selalu harus mengacu kepada konsep Sejahtera Paripurna yaitu konsep Sehat Organisasi Kesehatan Dunia (WHO) yang mengemukakan bahwa Sehat adalah: Sejahtera Jasmani, Rohani dan Sosial, bukan hanya bebas dari Penyakit, Cacat ataupun Kelemahan. Dalam kaitan dengan hal ini maka Pendidikan Jasmani dan Olahraga khususnya di lingkungan Lembaga Pendidikan, harus diselaraskan untuk mencapai tujuan sehat termaksud di atas, yang merupakan sehat seutuhnya yaitu Sejahtera Paripurna.

Pendidikan Jasmani dan Olahraga membina mutu sumber daya manusia melalui 
pendekatan kepada aspek Jasmani. Namun demikian Olahraga mempunyai potensi besar untuk juga mengembangkan aspek rohani dan aspek sosial.Pada dasarnya tujuan pembinaanpemeliharaan Kesehatan adalah memelihara dan/atau meningkatkan kemandirian dalam peri kehidupan bio-psiko-sosiologisnya, yaitu secara biologis menjadi (lebih) mampu menjalani kehidupan pribadinya secara mandiri, tidak tergantung pada bantuan orang lain; secara psikologis menjadi (lebih) mampu memposisikan diri dalam hubungannya dengan Tuhan semesta alam beserta seluruh ciptaanya berupa flora maupun fauna (termasuk manusia); dan secara sosiologis menjadi (lebih) mampu bersosialisasi dengan masyarakat lingkungannya. Meningkatnya kemampuan mandiri dalam peri kehidupan bio psiko sosiologis ini berarti meningkatnya kemampuan dan kualitas hidup yang berarti juga meningkatnya kesejahteraan hidup, yang senantiasa harus mencapai ketiga aspek Sehatnya WHO Masa pertumbuhan dan perkembangan anak adalah masa pembentukan pola perilaku dan masa terjadinya internalisasi nilai-nilai sosial dan kultural. Oleh karena itu wujud kegiatan Pembinaan-pemeliharaan Kesehatan bagi Peserta Didik harus ditujukan untuk mendapatkan ketiga aspek Sehatnya WHO tersebut di atas.

Kegiatan untuk meningkatkan kesejahteraan rohaniah dilakukan dengan upaya menunjukkan dan menyadarkan posisi dirinya dalam hubungannya dengan Tuhan semesta alam beserta seluruh ciptaanNya, serta dengan menanamkan rasa tanggung jawab yang tinggi terhadap pelestarian lingkungan sebaik-baiknya dan percaya diri yang tinggi namun rendah hati. Perlu juga ditanamkan kesadaran untuk mau melakukan upaya-upaya untuk menyegarkan suasana kehidupan, mencerdaskan kemampuan intelektual dan menghilangkan sebanyak mungkin stress, serta dengan meningkatkan volume dan kualitas pemahaman dalam peri kehidupan beragama beserta peningkatan kualitas pelaksanaan ibadahnya.

Olahraga baik sebagai kegiatan maupun sebagai media Pendidikan mempunyai potensi yang besar untuk menyumbangkan kontribusinya dalam masalah ini. Melalui Olahraga dapat dengan mudah ditunjukkan betapa terbatasnya kemampuan manusia, betapa perlu kita memelihara lingkungan hidup kita, betapa banyak hal yang di luar kemampuan akal manusia dan betapa perlu kita mencegah kerusakan dan perbuatanperbuatan yang dapat menimbulkan kerusakan di muka bumi.

Kesejahteraan jasmaniah ditingkatkan dengan Olahraga Kesehatan, untuk meningkatkan derajat Kesehatan dinamis, sehingga orang bukan saja sehat dikala diam (Sehat statis) tetapi juga sehat serta mempunyai kemampuan gerak yang dapat mendukung setiap aktivitas dalam peri kehidupannya sehari-hari (Sehat dinamis). Olahraga Kesehatan umumnya bersifat massaal sehingga lebih menarik, semarak serta menggembirakan (aspek Rohaniah), seperti yang terjadi pada pelaksanaan Pendidikan Jasmani dan Olahraga di Lembaga-lembaga Pendidikan. Berkelompok merupakan sarana dan rangsangan untuk meningkatkan kesejahteraan Sosial, oleh karena masingmasing individu akan bertemu dengan sesamanya, sedangkan suasana lapangan pada Olahraga (Kesehatan) akan sangat mencairkan kekakuan yang disebabkan oleh adanya perbedaan status intektual dan sosial ekonomi para Pelakunya.

Oleh karena itu Olahraga Kesehatan hendaknya dijadikan materi pokok dalam Pendidikan Jasmani dan Olahraga di Sekolah maupun Pesantren. Dampak psikologis yang sangat positif dengan diterapkannya Olahraga Kesehatan sebagai materi pokok Pendidikan jasmani dan olahraga di Sekolah adalah rasa kebersamaan dan kesetaraan di antara sesama siswa oleh karena mereka semua merasa mampu melakukan Olahraga Kesehatan dengan baik. Sebaliknya, bila Olahraga kecabangan yang diterapkan di Sekolah, yang sering menjadi sesat ke arah Olahraga Prestasi, dapat menyebabkan sebagian siswa merasa terpinggirkan dari kegiatan olahraga karena merasa tidak mampu untuk berprestasi.

Konsep Olahraga Kesehatan adalah: Padat gerak, bebas stress, singkat (cukup 10-30 menit tanpa henti), adekuat, massaal, mudah, murah, meriah dan fisiologis (bermanfaat dan aman). Massaal : Ajang silaturahim, ajang pencerahan stress, ajang komunikasi social. Jadi Olahraga Kesehatan membuat manusia menjadi sehat Jasmani, Rohani dan Sosial yaitu Sehat seutuhnya sesuai konsep Sehat WHO. Adekuat artinya cukup, yaitu cukup dalam waktu (10-30 menit tanpa henti) dan cukup dalam intensitasnya. Menurut Cooper (1994), intensitas Olahraga Kesehatan yang cukup yaitu apabila denyut nadi latihan mencapai 65-80\% DNM (Denyut nadi 
maximal: 220-umur dalam tahun). Masalah intensitas yang adekuat ini harus menjadi perhatian bila Olahraga Kesehatan telah mencapai Sasaran-3 (lihat Sasaran Olahraga Kesehatan).

Contoh Olahraga Kesehatan berbentuk senam yang dapat mencapai Sasaran-3 (Aerobik) ialah Senam Pagi Indonesia seri D (SPI-D). Satu seri SPI-D memerlukan waktu 1'45', sehingga untuk memenuhi kriteria waktu yang adekuat maka SPI-D harus dilakukan minimal $6 x$ berturut-turut tanpa henti, yang akan mencapai waktu 10.5 menit. Menurut penelitian, bila SPI-D dilakukan dengan sungguh-sungguh maka intensitasnya dapat mencapai tingkat adekuat sesuai kriteria Cooper. SPI-D ini macam gerak dan tataurutannya sudah berpola tetap sehingga lamakelamaan Peserta dapat menjadi hafal akan macam gerakan dan tata-urutannya. Bila Peserta sudah hafal, maka rangsangan terhadap proses berpikir menjadi berkurang. Oleh karena itu senam aerobik pada umumnya yang tidak berpola tetap, adalah lebih baik dalam hal rangsangannya terhadap proses berpikir.

Perlu diketahui bahwa pada kelompok anak dengan usia kronologik yang sama terdapat perbedaan yang cukup luas dalam tingkat kematangan psikologiknya, demikian pula terdapat perbedaan yang cukup luas pada umur biologiknya (Watson,1992). Umur kronologik adalah bilangan yang menunjukkan berapa kali seorang anak telah berulang-tahun, sedangkan umur biologik adalah tingkat kemampuan biologik (jasmaniah) anak yang sesuai dengan kemampuan yang ditunjukkan oleh sesuatu tingkat umur kronologik terntetu. Pada anak-anak, rentangan kemampuan biologik mereka berkisar sekitar 6 (enam) tahun. Misalnya, anak umur 10 tahun, kemampuan biologiknya berkisar antara kemampuan biologik anak umur 7 (tujuh) tahun sampai dengan kemampuan biologik anak umur 13 tahun (Watson 1992).

Dampak lebih lanjut dari rasa terpinggirkan ialah timbulnya kebencian terhadap olahraga. Kondisi demikian merupakan kondisi psikologis yang sangat tidak menguntungkan bagi perkembangan dan penyebarluasan olahraga di masyarakat. Dengan pengelolaan yang baik maka suasana lapangan dikala melakukan olahraga kesehatan, akan sangat meningkatkan gairah dan semangat hidup para pelakunya. Demikianlah maka potensi Pendidikan Jasmani dan Olahraga sangat perlu difahami oleh semua fihak yang berkepentingan dalam pembinaan Peserta didik. Oleh karena itu pula maka tanpa Pendidikan Jasmani dan Olahraga, maka sesungguhnya Pendidikan menjadi tidak lengkap.

Pendidikan jasmani dan Olahraga yang disajikan haruslah yang bersifat massal dan memenuhi ciri olahraga kesehatan misalnya: jalan cepat atau lari lambat (jogging), senam aerobik, pencak-silat, karate dan sejenisnya. Tiga yang terakhir lebih baik dari pada yang pertama oleh karena dapat menjangkau semua sendi dan otot serta dapat merangsang proses berpikir Pelakunya. Kalaupun olahraga yang akan disajikan adalah bentuk permainan, maka permainan itu harus dapat melibatkan seluruh siswa. Tidak boleh ada seorangpun siswa yang hanya menjadi penonton, kecuali yang sakit. Sehingga proses pembelajaran dapat berlangsung sesuai tujuan pembelajaran pendidikan jasmani dan olahraga tersebut.

Permasalahan yang berlangsung selama ini di Indonesia adalah kurikulum pendidikan jasmani dan olahragayang ada,tidak mendukung dalam menerapkan konsep pendidikan jasmani dan olahraga di sekolahsekolah. Sehingga implemantasi pendidikan jasmani dan olah raga tidak maksimal. Penyebabnya adalah (1) Proses pembelajaran mata pelajaran Pendidikan jasmani dan olahraga disekolah hanya 2 x 45 menit/minggu (2)Sarana dan prasarana sangat terbatas (3) Kurangnya jumlah Sumber Daya Manusia (4) Rendahnya kualitas Sumber Daya Manusia yang ada saat ini (5) Kurikulum Penjas dan olahraga lebih berorientasi kepada Olahraga olahraga prestasi.

Untuk mengatasi permasalahan Pendidikan jasmani dan olahraga di Indonesia ada beberapa solusi-solusi yang dapat ditempuh antara lain; (1) Pemerintah harus memiliki komitmen yang kuat dalam memajukan Pendidikan Jasmani dan olah raga pada setiap jenjang pendidikan, mengingat pentingnya pendidikan jasmani dan olahraga bagi kehidupan bangsa (2) Perlu kebijakan pemerintah dalam hal ini menteri pendidikan, dengan membuat konsep pendidikan Jasmani yang ideal sesuai karakteristik bangsa Indonesia, melalui tahapan penelitian, proses dan evaluasi dengan menentukan bench mark konsep pendidikan jasmani pada tingkat internasional (3) Untuk sekolah dasar kelas 1 s/d 3 sebaiknya hanya pendekatan permainan saja, belajar di alam, mengenal lingkungan sekitar. Dilatih keterampilan bidang musik, 
gambar lewat permainan. Jangan di masukkan semua mata pelajaran seperti sekarang ini. Menyebabkan anak menjadi bosen dan jenuh, kemandirian tidak ada, pengetahuannya juga tidak banyak. Karena sifat anak adalah bermain dan ingin tahu yang tinggi, kurikulum kita belum paham akan karakteristik anak-anak (4) Fasilitas penunjang pembelajaran pendidikan jasmani dan olahraga harus dilengkapi sesuai kebutuhan kurikulum, fasilitas permainan dan olahraga standar internasional. Terkait hal tersebut pengadaan prasarana juga harus adanya pemerataan, di seluruh provinsi di Indonesia sampai kepedesaan harus mendapatkannya (5) Untuk kelas $4 \mathrm{~s} / \mathrm{d}$ kelas 6 kurikulum ditambahkan dengan materi-materi pelajaran seperti sekarang ini. Fasilitas diperlengkap, seluruh sekolah dasar memiliki prasarana permainan terlengkap mendukung pembelajaran ini sampai pada tingkat pedesaan (kampung). Olahraga prestasi sudah diperkenalkan dan sudah mulai ada pembinaan usia dini pada cabang olahraga tertentu, seperti senam, renang, bela diri dll, tetapi belum ada penekanan dalam pembinaan (6) Guru-guru pendidikan jasmani yang ada di sekolahsekolah dasar harus ditambah dan ada evaluasi dari tenaga ahli Fakultas Ilmu Keolahragaan untuk mengontrol perkembangan anak selama di sekolah (disesuaikan dengan waktu dan kebutuhan). Perhatian khusus pada anak-anak di sekolah harus di tingkatkan karena merupakan aset bangsa, melalui Pendidikan jasmani dan olahraga menjadikan anak-anak di Indonesia bermartabat (7) Untuk pembelajaran tingkat lanjutan Sekolah Menengah Pertama (SMP). Kurikulum pendekatan sains sudah dimasukkan, dengan tidak menghilangkan kurikulum Pendidikan jasmani dan olahraga (aktivitas permainan) karena cendrung usia ini masih senang dengan permaninan. Keterampilan anak sangat dituntut pada usia ini. Untuk olahraga prestasi sudah di masukkan pada kurikulum dan ekstrakurikuler (8) Untuk sekolah lanjutan setara Sekolah Menengah Atas (SMA), kurikulum sekolah dituntut anakanak sudah ahli dan memiliki spesialisasi masing-masing dan siap terjun di dunia kerja sebagai ahli diberbagai bidang. Kurikulum Pendidikan jasmani dan olahraga tetap dimasukkan dan sudah mengarah pada olahraga prestasi (9) Pada pendidikan tinggi, dosen dan para pakar olahraga lebih banyak meneliti dan evaluasi terhadap konsep Pendidikan jasmani dan olahraga yang berjalan dan melahirkan inovasi-inovasi baru dalam pendidikan jasmani. Pendidikan tinggi juga harus melahirkan atlet-atlet yang berprestasi untuk mendongkrak keolahragaan nasional (10) Melibatkan perguruan tinggi dalam mengelola olahraga di Indonesia dan membangun fasilitas olahraga standar internasional pada setiap perguruan tinggi negeri. Dengan memfokuskan anggaran olahraga pada perguruan tinggi kurang lebih 30 milliar pertahun pada tiap perguran tinggi dengan audit yang terjadwal dan transparansi (11) Meningkatkan Sumber Daya Manusia Keolahragaan dari kalangan institusi, lembaga formal, badan pengelola keolahragaan, induk-induk organisasi secara nasional baik pelatihan, study banding, penelitian, magang dan lain-lain terkait pembangunan keolahragaan secara nasional.

\section{KESIMPULAN \& SARAN}

Bahwa pendidikan jasmani adalah bagian yang integral dari pendidikan keseluruhan, Pendidikan jasmani dalam konteks pendidikan nasional masih dianggap belum begitu penting oleh para pengambil kebijakan pendidikan Nasional. Dengan demikian akan sulit mengharapkan Pendidikan jasmani dan olahraga dapat berperan besar dalam menata sistem pendidikan yang semerawut ini.

Pendidikan Jasmani dan Olahraga di Lembaga Pendidikan harus ditekankan pada olahraga kesehatan dan latihan jasmani untuk meningkatkan derajat sehat dinamis dan kemampuan motorik dan koordinasi yang lebih baik. Agar para siswa selama masa belajar memiliki kualitas hidup yang lebih baik, serta dapat diharapkan dapat berprestasi di bidang akademik dan olahragasehinggamenjadi sumber daya manusia yang bermutu di masa depan.

Pemerintahan Indonesia harus berbenah diri dulu dengan menjadikan pendidikan jasmani dan olahraga sebagai kebutuhan dan pemerintah tertinggi harus memiliki komitmen yang kuat dan fokus dalam memajukan pendidikan jasmani dan olahraga di tanah air. Pemerintahan adalah kunci utama, pengambil kebijakan dan memajukan pendidikan di tanah air. Pemerintah dan para menteri terkait harus sinergis dan koordinasi yang baik dalam memajukan pendidikan jasmani dan olahraga pada lembaga pendidikan menuju Indonesia berkualitas Internasional.

\section{Saran}


1. Pemerintah harus memiliki komitmen yang kuat dalam memajukan pendidikan jasmani dan olahraga pada lembaga pendidikan di Indonesia

2. Pemerintah harus mampu mengelola pendidikan nasional dengan menggandeng tenaga pendidikan, para ahli dan pakar di Universitas seluruh Indonesia serta melakukan pengawasan dari masyarakat serta transparansi penggunaan anggaran

3. Pemerintah harus merubah kurikulum pendidikan jasmani dan olahraga di Indonesia mulai dari pendidikan dasar sampai pendidikan tinggi polanya harus berkesinambungan, membuat konsep pendidikan jasmani dan olahraga yang ideal sesuai karakteristik bangsa Indonesia melalui proses penelitian, pelaksanaan dan evaluasi serta bench marknya.

4. Pemerintah harus fokus dalam peningkatan sumber daya manusia melalui ilmu pengetahuan dan teknologi yang berstandar memiliki sertifikasi sesuai standar kemampuan dan selalu di evaluasi; Baik dosen, guru-guru pendidikan jasmani, pelatih

5. Pemerintah harus fokus membenahi dan menambah prasarana pembelajaran pendidikan jasmani di sekolah-sekolah Indonesia berstandar Internasional

6. Pemerintah harus fokus dalam membudayakan olahraga pada masyarakat Indonesia, agar masyarakat Indonesia menjadikan olahraga sebagai kebutuhan sehingga pemassalan terjadi dan memudahkan dalam perekrutan atlet yang berpotensi.

7. Pemerintah bersama anggota DPR dan DPRD harus fokus dan berkomitmen memajukan pendidikan berkualitas di Indonesia menuju Indonesia kualitas Internasional

8. Pemerintah sebaiknya meniru Negaranegara yang maju pendidikan jasmani dan olahraganya dan di implementasi di Indonesia dengan menggunakan manajemen yang efektif dan efisien.

9. Optimalisasi Pemberdayaan kelembagaan pendidikan dengan tujuan agar lembagalembaga terkait mampu berkembang makin meningkat kualitas dan karyanya

10.Mereposisi penggunaan olahraga/kegiatan pendidikan jasmani dan olah raga sebagai media pendidikan dan penggunaan olahraga sebagai alat pelatihan untuk memelihara dan meningkatkan derajat sehat dinamis menuju kondisi sejahtera paripurna sesuai konsep Sehat WHO

11.Menambah jam pertemuanpendidikan jasmani dan olahraga di sekolah $2 \times 45$ menit/minggu, dapat disajikan sebagai materi untuk $2 \mathrm{x}$ pertemuan/minggu dengan mengoptimalkan Sumber daya manusia yang memiliki kompetensi yang sesuai.

12. Optimalisasi olahraga prestasi perlu pula dikembangkan namun sebaiknya ditempatkan sebagai materi ekstra kurikuler, sebagai tempat penyaluran bakat dan minat pelajar.

\section{DAFTAR PUSTAKA}

Abdul Kadir Ateng, Peranan Pendidikan Jasmani dan Olahraga Dalam Mencapai Tujuan Pendidikan, Jakarta: ISORI DKI, 1993

Abdul Kadir Ateng, Azas dan Landasan Pendidikan Jasmani, Jakarta: FPOK IKIP Jakarta, 1992

Aip Syarifuddin, Pengembangan Kompetensi Guru Pendidikan Jasmani dan Kesehatan Dalam Mengelola Program Pembelajaran Gerak, Jakarta: PPPITOR Menpora, 1999

Bappenas, Pendidikan dan generasi muda: Bappenas, (On Line), $\mathrm{http} / /:$ www.bappenas.go.id/get-fileserver/node/5814/ hal 406 (di akses 23 April 2012)

Bambang A.J, Peran Pendidikan Jasmani; On Line (di akses 12 September 2012), http : // file . upi . edu / Direktori / FPOK / JUR. PEND. OLAHRAGA 196509091991021 BAMBANG ABDULJABAR / Peran Pendidikan Jasmani. pdf

Cooper, K. $\bar{H}$. Antioxidant Revolution. Nashville-Atlanta-London-Vancouver: Thomas Nelson Publishers. 1994

Depdiknas, Draft Rencana Strategis Direktorat Jenderal Pendidikan Tinggi 2010-2014: Direktorat Jenderal Pendidikan Tinggi, (On Line), http : // www . dikti . go . id / tatalaksana /hukum/ index.php?option $=$ com content\&view $=$ art icle\&id=53:renstra-kementrianpendidikan-nasional-20102014\&catid $=7$ :peraturanmenteri\&Itemid $=11$ (di akses 2012)

Depdiknas, Konsep: BAN-PT, (On Line), http://ban-pt . kemdiknas . go .id /index. php?option $=$ comcontent \&view $=$ article\&i $\mathrm{d}=51 \&$ Itemid $=56 \&$ lang $=$ in $\quad(\mathrm{di}$ akses 23 April 2012) 
Giriwijoyo,Y.S.S. Ilmu Faal Olahraga. Bandung: Buku perkuliahan Mahasiswa FPOK-IKIP.1992

Giriwijoyo,H.Y.S.S. dan H.Muchtamadji M.Ali. Makalah Pendidikan Jasmani dan Olahraga di Sekolah.IKIP Bandung: Fakultas Pendidikan Olahraga dan Kesehatan. 1997

Giriwijoyo,H.Y.S.S.Olahraga Kesehatan. Bandung: Bahan perkuliahan Mahasiswa FPOK-UPI. 2000

Giriwijoyo,H.Y.S.S. Makalah Pendidikan Jasmani dan Olahraga, kontribusinya terhadap Pertumbuhan dan Perkembangan Peserta Didik, Jawa Barat Indramayu: Ma'had Al-Zaytun, Haurgeulis. 2001

Kementrian Pemuda dan Olahraga, Rencana Strategis Kementrian Pemuda dan Olahraga Tahun 2010-2014. Jakarta: Kementrian Pemuda dan Olahraga. Tahun 2010.

Komisi Disiplin Ilmu Keolahragaan (KDIKeolahragaan), Ilmu Keolahragaan dan Rencana Pengembangannya: Depdiknas Direktorat Jendral Pendidikan Tinggi, Kerjasama atas ISORI Pusat, 2000

Nana Sudajana dan Ahmad Rivai, Teknologi Pengajaran, Bandung: Sinar Baru Algensindo, 2000

Republik Indonesia, Undang-undang Sistem Pendidikan Nasional Tahun 2003: Diknas, (On Line), http://luk.staff.ugm.ac.id/atur/UU202003Sisdiknas.pdf (di akses 23 April 2012)

Republik Indonesia, Undang-Undnag Sistem Keolahragaan Nasional No.3 Tahun 2005: Kemenpora, (On Line), http : // portal. mahkamahkonstitusi go.id/ eLaw / mg58ufsc89hrsg /uu32005.pdf hal 2 (di akses 22 April 2012)

Syarifudin, Kunci Sukses Pengembangan Program Pendidikan Jasmani, Jakarta: Ardadizya Jaya, 2000

Tabrani Rusyan, Tatang Kusdinar dan Zaenal Arifin, Pendekatan dalam Proses Belajar Mengajar, Bandung: CV. Remaja, 1998

Unesa, Profil Singkat dan SDM Jurusan Pendidikan Kesehatan dan Rekreasi: Unesa, (On Line), http://fik.unesa.ac.id/?s=menu\&id=20110 5280003 (di akses 23 April 2012)

UPI, FIK: Universitas Pendidikan Indonesia, $(\mathrm{On}$ Line), http://www.upi.edu/profil/fakultas/fakulta s-pendidikan-olahraga-dan-kesehatan (di akses 23 April 2012)

Watson,A.S. Children in Sports. Blackwell Scientific Publications: dalam Textbook of Science and Medicine in Sport Edited by J.Bloomfield, P.A.Fricker and K.D.Fitch. 1992

Wiranto Arismunandar, Masa Depan Pendidikan Jasmani dan Olahraga di Indonesia, Bandung: Pusat Olahraga ITB, 1991

, Implementasi Program Pendidikan Jasmani; On Line (di akses 15 Juni 2012)http://Pendidikan jasmani dan olahragaorkeszone.blogspot.com/2012/02/implementasi -program-pendidikan-jasmani.html , Pengertian defenisi olahraga; On Line, (di akses 14 Juni 2012) http://carapedia.com/pengertian definisi olahraga info2059.html

,Defenisi Olahraga; On Line, (di akses 14 Juni 2012), http://kumpulan-artikelolahraga.blogspot.com/2012/01/definisiolahraga.htmlDefinisi Olahraga , Implementasi Program Pendidikan Jasmani; On Line, (di akses 9 Juni 2012), http://Pendidikan jasmani dan olahragaorkeszone.blogspot.com/2012/02/implementasi -program-pendidikan-jasmani.html 